\title{
Metastatic Squamous Cell Carcinoma in Cervical Lymph Node
}

National Cancer Institute

\section{Source}

National Cancer Institute. Metastatic Squamous Cell Carcinoma in Cervical Lymph Node. NCI Thesaurus. Code C157452.

A squamous cell carcinoma that has spread from its original site of growth to a cervical lymph node. 